\title{
The Importance of Preservation of Autochthonous Biotope of Pannonian Plane in the Area of Special Nature Reserve "Pašnjaci Velike Droplje" for Education and Ecotourism Development
}

\author{
Milana Pasic* \\ Dragan Dolinaj* \\ Vladimir Stojanovic*
}

\begin{abstract}
In the past the region of Vojvodina was dominated by vast steppes, saline areas, marshes and flooded terrains. Wet terrains were converted into steppes during the Holocene climate changes, but the land under cultivation is gradually taking their place, too. Autochthonous biotope is preserved in some regons of Vojvodina. These regions are under state protection. Special nature reserve "Pašnjaci velike droplje" consists of saline areas and vast steppes and it is the only habitat of Great Bustard in Serbia. Reserve is located in north Banat. Devolpment of ecotourism is based upon endangered ornithology species, heterogeneous fauna as well as upon up the educational purpose of the reserve. There are also possibilities for organizing of photo safaris and nature schools in the reserve. In order to protect autochthonous biotope, legal regulations on protection should be obeyed, fields should be revitalized i.e. they should be transformed into former state of natural mosaic of vast steppes and saline areas.
\end{abstract}

Key words: reserve, Great Bustard, ecotourism, Banat.

\section{Introduction}

Pannonian basin was covered with alluvial planes with marshy, swampy terrains, saline areas and vast steppes. Swampy terrains disappeared during the Holocene climate changes. Land under cultivation was also taking their place in the past centuries. The remains of former swamps, marshes, meadows and saline areas have been preserved in the nature reserve "Pašnjaci velike droplje" which is situated in the area of Banat in Serbia.Nature reserve "Pašnjaci velike droplje" is situated in the plain of north Banat, at the alluvial plane of the river Zlatica, north-

\footnotetext{
* Faculty of Science, Department of geography, tourism and hotel management, Novi Sad, www.ig.ns.ac.yu
} 
east of Kikinda. (Map1). Devolopment of ecotourism in the area of nature reserve could ensure necessary financial means for reserve protection. Biodiversity, as well as numerous endangered species can become basis for touristic valorization of reserve area with indispensable analysis of the influence of tourism upon endangered species, which would confirm sustainability of these activities in the reserve area. Tourism development would contribute to development of local community and better life standard of the population. Development of ecotourism in reserve area would also contribute to the education of visitors. Thus, educational role would contribute to better understanding not only of protected area, but environement in general.

\section{Size, borders and characteristics of protection of nature reserve "Pašnjaci velike droplje"}

Nature reserve "Pašnjaci velike droplje" is geographically well-positioned, both in relation to geomorphological aspects and socially-geographical factors. The river Zlatica flows southwest from Romaninan border. The Zlatica is left contributary of the river Tisa. It has formed wide alluvial plane which represents huge contrast to present water abundance of the river. It is assumed that water abundance was much greater during one period of the Holocene, when alluvial plane was formed by intersection of loess terrain. Left side of alluvial plane was made of abandoned rivebeds, intersected meanders and swamps that represent remains of the former flow of the river. Pleistocene bend rafters represent remains of former loess plateau. Alluvial plane of the river Zlatica is connected to alluvial plane of the river Tisa in the southwest. Nature Reserve "Pašnjaci velike droplje" is situated on the left side of alluvial planes of the Zlatica and the Tisa. The teritory of reserve belongs to the municipalities Kikinda and Coka, or to be more precise, to the municipalities of Jazovo, Ostojicevo, Mokrin and Sajan. Reserve borders are between $45^{\circ} 52^{\prime} 48^{\prime \prime}$ and $45^{\circ} 55^{\prime} 15^{\prime \prime} \mathrm{N}$ and $20^{\circ} 16^{\prime} \mathrm{o} 9^{\prime \prime}$ and $20^{\circ} 19^{\prime} 52^{\prime \prime}$ E (Map 2). The area of the reserve occupies 979ha (Lazić, 2008). Reserve is situated between Mokrin, Banatski Monostor, Jazovo, Ostojicevo and Sajan. Kikinda, the centre of North Banat is situ-

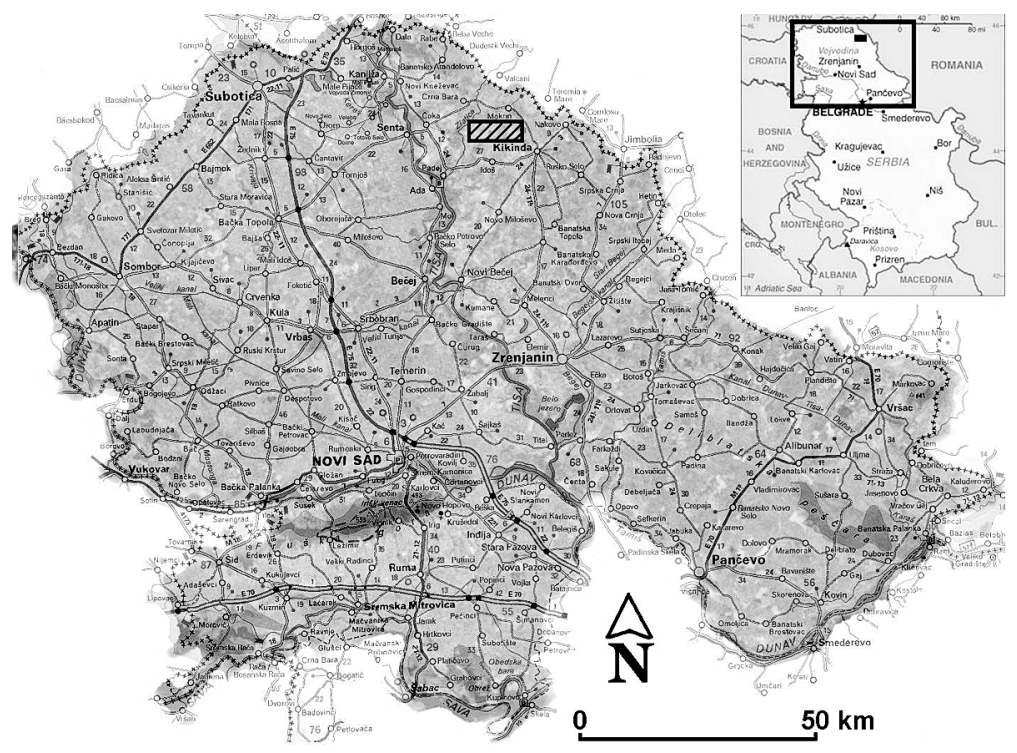

Map 1: Position of Special nature reserve Pašnjaci velike droplje 


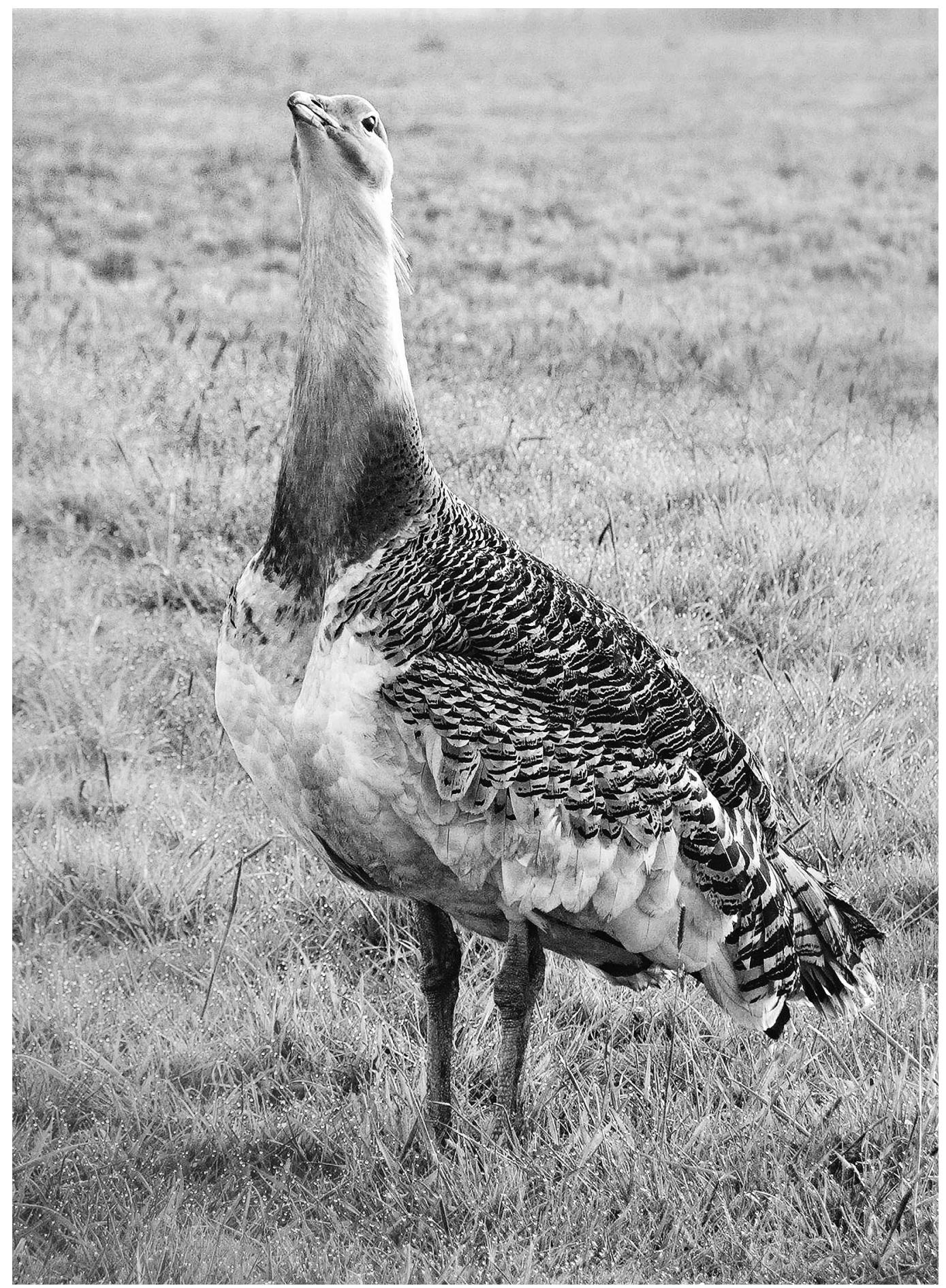

Picture 1: Great Bustard (Otis torda); Photo by: S.Puzovic 
ated south-east of the reserve. Main road Kikinda-Senta goes south of the reserve, the valley of the river Zlatica is situated in the north, and local road Idjos-Mokrin leads to the reserve from the east. Nature reserve can be rached by the regional road Mokrin-Banatski Monostor from the north. Besides Kikinda there are other settlements in the wide area of nature reserve. Senta is situated north of reserve, Becej is situated in the south, whereas Kanjiza is situated in the north-west. Reserve has favourable position. It is situated $70 \mathrm{~km}$ from Subotica and $80 \mathrm{~km}$ from Novi Sad (Map 1). Development of ecotourism in nature reserve is enabled by favourable position.

Ecotourism devlopment is based upon endangered and rare species, but also upon preserved rare ecosystems and biocomplexes in the areas protected by the law. Endangered bird species of Great Bustard (Otis tarda) (Picture 1) is the most important value of nature reserve "Pašnjaci velike droplje". The first traces of Great Bustard were found in Germany and France in the layers of brown coal whose age was estimated to 65 to 70 million years. The first traces in Pannonian plane are 350-400 thousand years old. (Kreitzoi, 1962). Great Bustard can be seen in different areas from North Europe to middle Asia. It can be found in the north of Africa, south Portugal, Spain, Germany, Poland, Hungary, Serbia, Romania, Bulgaria, The Ukraine, Russia, Iraque, Iran, Kazahstan amd north Siria. However, areal fragmenatation could be noticed both in Europe and Asia. At certain regions its number became smaller.( Fodor, 1971). Great Bustard is considered to be a resident bird in Serbia, especially in the regions north of the Sava and the Danube. (Matvejev, 1950). Its number was considered to be the greatest at the end of XVIII century. Dissapearance of habitat, as well as the fact that Great Bustard was hunting animal untill the second half of the XX century,contributed to areal fragmentation. (Tomić and assoc., 2004). Great Bustard is an extremely huge bird. Males could reach the height of $1 \mathrm{~m}$,

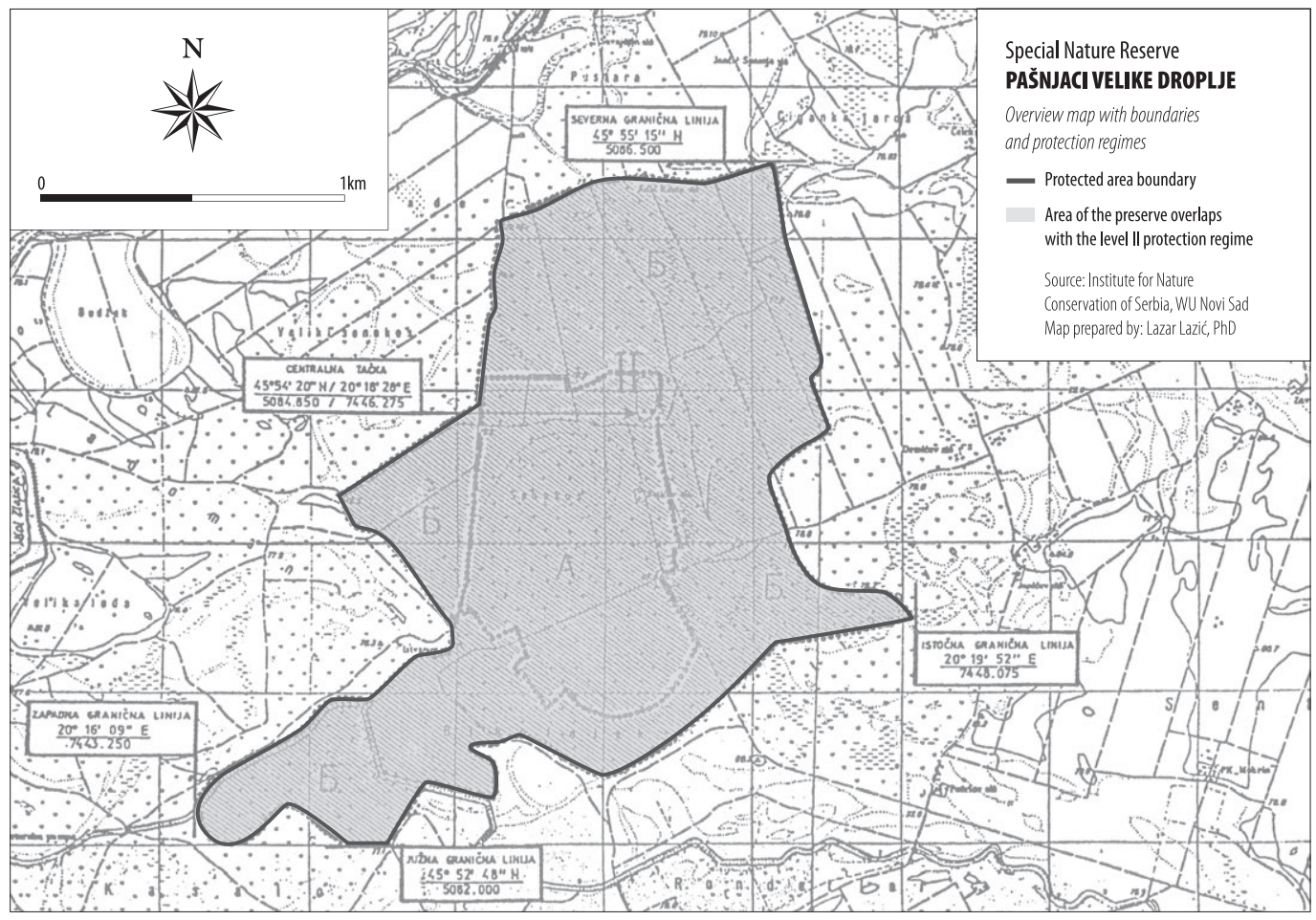

Map 2: Special nature reserve "Pašnjaci velike droplje" 
and females can reach the height of o,8m. Males' weight could vary from 8 to 16 kilos, whereas females weigh from 4 to 8 kilos. Some specimen could weigh more than 24 kilos (the specimen was registered at the reserve area). Males and females have similar feather colour. Upper part of their body is yellow-reddish with dark spots. Males aslo have characteristic "moustaches" made of long feathers on their cheeks. During the season period males show-off in front of the females by raising and spreading their wings and tails (Lazić, 2008). Great Bustard finds optimal conditions for nesting in the moist meadows. Terrains withoout grass or with very low grass layer are not suitable for nesting. Thus, saline areas do not suit the species. Great Bustard is also on European red list of globally endangered species. It has the status of rare species, and it is also in Red Book of Endangered species of world. As a natural rarity it is protected by law in Serbia. (Tomić and assoc., 2004).

Thus, being endangered species, this bird is very popular with ecotourists who are willing to come across hundreds and thousands of miles just to see it and take some pictures.This statement is proved by the number of tourists who have come to the reserve from the most distant parts of the world. Numerous examples of flora and fauna that make characteristic biotope of the area can be seen in the reserve, besides Great bustard. Since the end of the spring the landscape of the reserve is characterized with Thyme (Thymus marschallianus), May Night (Salvia nemorosa) and St Johnwort (Hypericum perforatum). Rare species such as Dianthus pontederae subsp.pontederae, Pannonian Knapweed (Centaurea sadleriana), Plantago schwarzenbergiana and Silene viscoca can be seen in the meadows. The region is also inhabited by Perennial Pea (Trinia ramossisima), Musk Thistle (Lathyrus latifolius), Tawny Pipit (Carduus nutans), Whinchat (Anthus campestris), Welted Thistle (Saxicola rubetra) and Spiny Plumeless Thistle (Carduus acanthoide). Other representatives of ornithology fauna can be found in the reserve, besides Great Bustard. These are: Montagu's Harrier (Circus pygargus), Red-footed Falcon (Falco vespertinus), White Stork (Ciconia ciconia), Grey Partridge (Perdix perdix) and Short-eared Owl (Asio flammeus). There are also 1250 different species of insects, spiders, Orthoptera, bedbugs, dipterous insects, Hymenoptera and Coleoptera. The most important are: Ground Bettles (Carabidae), Scarab Bettles (Scarabaeidae), Swallowtail (Papilio machaon) and number of amphibians and reptiles. Nature reserve "Pašnjaci velike droplje" was proteceted by the law in 1997 by the regulation act of The Republic of Serbia. (Pavkov and assoc., 1999). The reserve occupies the area of 979,4ha, with the second level of protection, with separate $A(284,4505 \mathrm{ha})$ and B $(694,9889 \mathrm{ha})$ zones that are characterized by special sets of measures. (Institute of Environmental Protection, 1996.) (Map 2). Restrictions and controlled exploitation of natural resources were defined within the regime of the second level. Activities can be perforomed only if they coincide with the preservation of basic values of the reserve (Law on Environmental Protection).

\section{Possibilities of ecotorism devlopment, problems of protection and importance of education}

During the last two decades of the twentieth century, ecotourism has become more important in Europe. This type of tourism, which was typical of North America, became more popular in Europe at the moment when people became more aware of the importance of environmental protection. At that period numerous national reserves and parks in the "old' continent became more attractive to greater number of touristis. Development of new type of tourism has stated the need for new areas that could be protected and affirmed as ecotourism goals. Protected areas in Serbia have been out of reach of tourism for a long time. They were used 
solely for scientific research and protection of certain species. The idea of turning protected areas into ecotourism destinations was influenced by European tourist movements. New tourist movements are being considered in nature reserve "Pašnjaci velike droplje", too. Still, ecotourism potential of the reserve is quite small. The reserve has the protected area of 979ha, which is not attractive enough for foreign tourists. Flora and fauna diversity is not enough to become the basis for advertising and commercial presentation. The only significant ecotourism value of the protected area is endangered bird species, Gread Bustard. It is extremely rare in the region of Europe, special nature reserve is it's only habitat in Serbia. This fact explains its appeal to touristis. Bird watching, which is becoming more and more popular in the world, gains its supporters in Serbia, too. Their huge interest in endangered species of Great Bustard was confirmed by fact that nature reserve was visited by numerous fans of bird watching. Bird watching could become basis for ecotourism development in the area of nature reserve "Pašnjaci velike droplje", but only if problems of relatively small number of specimen and small area of reserve are solved. There are also other problems in the protected area. Quality of management of nature reserve "Pašnjaci velike droplje"was questioned, too. Protected area was used as hunting area and partly as agricultural land. Agricultural activities are connected to cattle raising and husbandry. Land under cultivation occupies $14 \%$ or 137 ha of the reserve area. Grain, maize, sunflower and alfaalfa are also raised there. Cattle is raised at the fields, at $45 \%$ or 440,7 ha of the reserve area. Meadows occupy $32 \%$, or 313,4 ha and they are regularly mowed. All these activities in the reserve negatively influence flora and fauna of the reserve. They also directly endanger the Geat Bustard. Steppe areas which represent natural habitat and place of nesting of Great Bustard are converted into land under cultivation. Uncontrolled cattle breeding at the area of reserve negatively influences the birds and their nests in the grass. Cows, pigs and sheeep often step over bird eggs on the ground, and pigs do not hesitate to eat eggs and nestlings. Nests in the meadows are often destroyed during the mowing. The analysis shows that there is no agricultural activity at only 89 ha or $9,1 \%$ of reserve. However, it seems that Great Bustard is edangered even in the rest $9 \%$ of the area because the entire teritory of the reserve is used as hunting area. But, this is not all. Broken cars, vans, or machinery used in agriculture can be seen in steppes, meadows, swamps and saline areas. Garbage does not only influence the esthetic image, but it also frightens the animals. There is no solution to these problems in near future, and realization of newly-made plans can only create new ones. Building of carp pond at one part of the reserve would destroy swamp areas and meadows. Thus, flora would be endangered and the ecobalance of the reserve would be disturbed. Higher amount of water surfaces would bring about to greater number of typical swampbirds which would cause the smaller number of steppe species, i.e. the number of endangered Great Bustard. Education of local population could partially solve this problem. In case local community realized the importance of the area as well as the value of flora and fauna of the reserve, their attitude to nature reserve would be changed. This approach has already given some results. (Stojanović, 2006). If cattle would not be bred at protected area, nestlings of Great Bustard as well as autochthonous flora would be less endangered. Local population would also benefit from ecotourism. Thus, their attitude to nature reserve "Pašnjaci velike droplje“. would be changed. Education of young people on the importance of enviromental protection would be of general interest. Educational process would influence young people and help them create positive ecological attitude. Organizing of nature schools is one type of education which would enable young people to acquire some knowledge about flora and fauna of the area ae well as about some problems of their survival. 


\section{Conclusion}

The presence of certain endangered or rare species makes some area atractive for ecotourism. Very presence of these species sometimes attracts great number of bird or animal lovers. Mutual realtionship of two factors is in an inverse proportion. If one species is more endangered and more rare, its ecotourism attractiveness is greater. Great Bustard has become endangered species since its number became smaller in the teritory of Europe. It has also become attractive for ecotourism. Nature reserve "Pašnjaci velike droplje" is the only habitait of the species at the teritory of Serbia. Estimated capacity of the reserve is around 6o specimen. If their number exceeded the capacity of the area, some couples could be moved to similar habitats in north or middle Banat. There are around thirty specimen of the species in the reserve at the moment. This number would be a starting point for development of ecotourism in the area of north Banat. Ecotourism valorization of the nature reserve and endangered species would contribute to acquiring greater knowledge about Great Bustard, as well as its survival in this area.

\section{References}

Kreitzoi, M., (1962): Tortenelem elotti tuzoki-lelet es a tuzokfelek tortenete, Aquila, Budapest. Lazic, L., Pavić, D., Stojanović, V., Tomić, P., Romelić, J., Pivac, T., Košić, K., Besermenji, S., Kicošev, S., Đarmati, Z., Puzović, S., Đureković-Tešić, O., Stojanović, T., Marić, B., Vig, L., Panjković, B., Habijan - Mikeš, V., Sabadoš, K., Delić, J., Kovačević, B., Stojšić, V., Korać, J. (2008): Zaštićena prirodna dobra i ekoturizam Vojvodine. Departman za geografiju, turizam i hotelijerstvo, prirodno-matematički fakultet, Novi Sad.

Matvejev, S., (1950): Zaštita ptica, Zaštita prirode, Beograd.

Pavkov, G., i drugi, (1999): Specijalni rezervat prirode Pašnjaci velike droplje. Predlog za stavljanje pod zaštitu kao prirodnog dobra od izuzetnog značaja. Zavod za zaštitu prirode Srbije, Odeljenje u Novom Sadu.

Stojanović, V. (2006): Održivi razvoj turizma i životne sredine. Departman za geografiju, turizam i hotelijerstvo, prirodno-matematički fakultet, Novi Sad.

Tomić, P., Romelić, J., Kicošev, S., Besermenji, S., Stojanović, V., Pavić, D., Pivac, T., Košić, K., Puzović, S., Habijan - Mikeš, V., Panjković, B., Sabadoš, K. Štetić, J., Kovačević, B., Stojšić, V., Korać, J. (2004): Zaštićena prirodna dobra i ekoturizam Vojvodine. Departman za geografiju, turizam i hotelijerstvo, prirodno-matematički fakultet, Novi Sad.

Vasić, V. (1984): Biogeografske karakteristike ptica vodenih staništa Balkanskog poluostrva. Doktorska disertacija, Prirodno-matematički fakultet, Beograd.

Zavod za zaštitu prirode Srbije, (1996): Elaborat „Predlog za zaštitu prirodnog dobra „Pašnjaci velike droplje" kao specijalnog rezervata prirode“. Novi Sad.

Zakon o zaštiti životne sredine. Službeni glasnik Republike Srbije, Broj 66/91, Beograd.

Zaštita prirode (1991): Prilog za prostorni plan Srbije (Plan zaštite prirodnih dobara). Republički zavod za zaštitu prirode, Beograd.

Fodor, T.,Nagy, L., Sterbetz, I., (1971): A tuzok, Mezogazdasgi kiado, Budapest. 